UDC 811.163.41'366.52

https://doi.org/10.18485/bells.2018.10.13

\author{
Boban Arsenijević \\ University of Graz \\ Graz, Austria
}

\title{
THE LANGUAGE OF DORIAN GRAY: WHY THE SOCIAL AND CULTURAL TREATMENT OF GENDERS CANNOT BE IMPROVED BY ACTING ON THEIR REFLECTIONS IN LANGUAGE
}

\author{
Drugo je pitanje da li se u gramatičkoj strukturi jezika, \\ za koju smo već ranije rekli da je po svojoj prirodi konzervativna, \\ mogu kriti relikti prevaziđenih društvenih odnosa u vezi s polom. \\ Odgovor je da mogu, iako često na način koji nije neposredno prepoznatljiv, \\ $i$ to daleko najčešće u znaku pune dominacije muškog principa. ${ }^{1}$ \\ Ranko Bugarski, Jezik i kultura
}

\begin{abstract}
The paper discusses the interaction of the feminist ideology and action on the one hand and the deeper structure of grammar and the lexicon on the other. It is argued that linguistic intervention propagated as a means of achieving a gender-equal and gender-sensitive language can neither be successfully realized, nor can it deal with a projection of language which has the intended properties. Furthermore, the claim that language shapes reality is contested, in favor of a view according to which language reflects our picture of reality and at the very best (or worst)

E-mail address: boban.arsenijevic@uni-graz.at

1 A different question is whether the grammatical structure of language, which, as we have already said, is conservative by nature, may be hiding relics of obsolete gender-related social relations. The answer is that it may, even if in a way which is not immediately recognizable, and most often through complete domination of the masculine principle.
\end{abstract}


helps us preserve it. I conclude that in a society in which gender is not an axis of discrimination - any linguistic status of gender would be equally good, yet such a society would probably also end up with a language in which gender has no role in grammar whatsoever.

Key words: grammatical gender, gender-equality, gender-sensitive language, Serbo-Croatian, linguistic economy

\section{Gender sensitive language in Serbia}

A detailed state of the art description of the area of gender sensitive language in Serbia would require a book rather than the introductory section of an article. My ambition in this section is only to give a relatively superficial overview, and introduce the reader to the ongoing debate around the Resolution of the Committee for Standardization of Serbian Language titled Језик родне равноправности - родно диференцирани језик и граматичка категорија рода у српском језику ('Language of gender-equality - genderdifferentiated language and the grammatical category of gender in the Serbian language', available at http://www.isj-sanu.rs/rubrike/odlukeodbora/103/2015/03/11/jezik-rodne-ravnopravnosti.html).

As in a number of other countries, especially those in the area of the former Yugoslavia, society in Serbia is polarized when it comes to gender equality. On the one hand, bearers of the feminist and related social activism are pursuing a program aimed at decreasing the level of inequality and discrimination based on gender. One of the central points of this program is the introduction and normalization of morphologically derived feminine terms (feminatives) for all of the professions, titles, social roles and other notions which include or have no reasons not to include, persons of both genders. The primary targets are terms referring to prestigious and/or positively connoted roles (akademik 'member of the Academy', vođa 'leader', borac 'fighter'), as there is a common understanding that the lack of feminatives for such notions lends support to the view that prestigious roles are reserved for men, or at least that men are more suitable to bear them. Since gender-sensitive principles of language use are still fighting for elementary instantiation - it is as yet unclear what if any limits are foreseen. At the moment, proponents of this struggle set an example in their texts, where indeed any reference to a female person by 
one of the relevant nouns uses a feminative (akademkinja 'female member of the Academy', vodkinja 'she-leader', borkinja 'she-fighter'). However, relatively few people use a disjunction of pronominal forms for free or bound pronouns (on/ona 'he/she', njega/nju 'him/her' in examples like: Svakome treba prijatelj koji će da mu(/joj) pomogne 'Everybody needs a friend to help him(/her)'; note that in Serbo-Croatian the plural form which is indeed gender-neutral is unacceptable in such contexts). Even scarcer is the use of a disjunctive slash for nouns with a free or quantified reference (Svaki policajac(/policajka) mora da zna da upravlja putničkim vozilom 'Every policeman(/policewoman) must be able to drive a car'), or of neutral nouns like osoba 'person' (Svaka osoba u policijskoj službi... 'Every person serving in the police...'), which is often, as exemplified, much more cumbersome in Serbo-Croatian than in English.

As the examples above illustrate, the way to derive feminatives in Serbo-Croatian chosen by virtually all the proponents of their introduction is suffixal derivation. Other possibilities are either grammatically or stylistically degraded (such as the prefixation of a pronoun: \#ona-voda 'she-fighter'), or simply ignored/rejected (such as the much more natural constructions of the type žena-vođa 'woman-leader').

On the other hand, there is the conservative part of the society, including the institutions which influence the generally accepted view of the standard language: Serbian language departments at state universities, the Serbian Academy of Sciences and Arts (SANU) and its Institute for the Serbian Language, Matica srpska (a cultural institution with a long tradition). Here, insisting on the use of feminatives is generally seen as a foreign influence which threatens to negatively affect the Serbian language, and as part of a broader ideological influence which endangers the 'Serbian national being'. These institutions are hence a source of strong resistance to the tendency of a consistent use of feminatives.

Through their strongly prescriptive orientation, which they manage to maintain as the dominant ideology throughout primary and secondary education (by schooling teachers with such views), these institutions strive to preserve the status of the authority to decide what is correct and what is not in what they refer to as the Serbian language.

In a relatively recent document entitled Језик родне равноправности родно диференцирани језик и граматичка категорија рода у српском језику ('Lanuage of gender-equality - gender-differentiated language and the grammatical category of gender in the Serbian language'), the Committee 
for the Standardization of the Serbian Language - a body established by the above-mentioned conservative institutions, formulates a somewhat softer view. While nothing has changed about the position of a language authority which decides what is and what is not correct, and while the view that grammatical categories are completely disconnected from cultural and social values and relations is explicitly stipulated to disqualify gender-sensitive language - the attitude toward gender-sensitive language is somewhat different than it used to be. This document acknowledges the need for specification of the feminine gender, but proposes that in cases where the derivation through suffixation yields forms which sound grammatically degraded (such as the nouns akademkinja, vodkinja, borkinja), the prefix žena-'woman-' should be used (žena-akademik'womanacademic', žena-vođa 'woman-leader', žena-borac 'woman-fighter'). This presents a considerable compromise compared to the original conservative position, as it accepts the need to establish and use feminatives.

The opposite side, however, immediately dismissed this view. The arguments were mainly that the prefixation of žena- is cumbersome, unusual, and even grammatically degraded, as well as that this still implies inequality since there is no counterpart prefixation of muškarac- 'man' for male referents.

\section{Complexity of language}

Language is one of the objects of the highest complexity among those which are part of the descriptive metaphysics of our everyday life, and even among those which exist in the ontologies of different scientific disciplines. Its complexity is such that the most powerful computational tools available to (wo)man today, able to compute highly accurate predictions regarding the behavior of particles at the quantum level, or the transformations of space, still give relatively poor results when it comes to the structural parsing of language. Extremely complex systems are typically also robust: unless there is a drastic change in the environment, they do not collapse, and they can hardly be controllably changed in a relatively short period of time. Language is also a multi-layered phenomenon along numerous dimensions. For instance, a language typically includes dozens of registers - specific realizations conditioned by particular social factors. Social changes thus often first affect only one register, and then gradually and 
indirectly the others, which is another mechanism to amortize external effects.

Language is also a phenomenon most pervasively intertwined with the life of the human individual and human society. The amount of linguistic activity in human society is enormous. This results in extreme pressure on language economy. Language needs to reach an equilibrium, an optimal balance between the utmost simplicity (i.e. the fastest possible processing), and the highest quantity of information carried. The robustness of language is a function of its complexity and this degree of pressure towards economy.

Considering the interaction of these extreme properties, it is no wonder language displays a degree of robustness shown by very few other systems. This is the reason why attempts to artificially change a language may make sense when it comes to a few memorized units such as words, or when it comes to a social group switching from one existing register to another, but are futile when it comes to language structure - to the utmost horror of the prescriptive linguist. It is highly unlikely that an artificial change in language could go without affecting its economy even in the smallest structural domain. But due to its interaction with other structural dimensions, and due to the amount of linguistic activity in the individual and in the society, even the smallest decrease in economy quickly causes a restoration of the more economic state.

Language is in constant change, but it is a change sufficiently slow and distributed across the different domains of language, to enable it to change from one to another state of equilibrium. Pressure for a change in one domain triggered typically by a change in the social and cultural embedding of language, pends the emergence of a set of other changes across other domains of language, which will enable the system to preserve its optimal balance between the time and energy required for its processing and realization and the amount and quality of information carried. The external pressure that causes a change in language in such cases is itself also robust: it is instantiated in an abundance of situations, both at the level of the society and of the individual. It acts as soft power: everything functions without the change, but the change offers a somewhat better match to the newly established environment.

In fact, since these changes are slow, there is a permanent state of multiple pressures and multiple changes, in different stages, which also interact with each other, thus representing another level of complexity of language. 


\section{Economy of gender (in Serbo-Croatian)}

The Serbo-Croatian gender system is based on three values, traditionally referred to as neuter, masculine and feminine, and formally analyzed in Arsenijević (2017) as the absence of gender (neuter), the unvalued gender (masculine) and the valued gender (feminine). The reason for this analysis is that except for a closed class of feminine nouns in a consonant, all inanimate and hence irrelevant for the issues of gender semantics and pragmatics, feminine gender always involves morphological marking which is often absent in masculines (slon 'elephant' : slon-ica 'she-elephant'). This markedness is not dependent on the feminine being derived from a masculine (muškarac : ̌̌en- $a$ 'man : woman', / : dadilj-a 'she-nanny'), but simply a property of its realization (more precisely - of its mapping to a marked declension class).

There are two important aspects of economy in the area of gender. One concerns the very formal feature of number, i.e. its values. In general, gender-based systems involve three different values, two of which correspond to actual semantic (biological / anthropological) notions of gender: masculine, related to males, and feminine, to females. However, in addition to referring to male and female individuals, there is also the need to refer to mixed groups. This means that in addition to the neuter, three other types of reference are required: feminine, masculine and mixed. However, these three types of reference are always grammatically realized in only two values of gender. The mechanism is the following.

One value of the formal feature of gender is specified as a disjunction of the two values (as masculine_or_feminine), and another as one particular value - in natural language typically as feminine (Corbett 1991 observes that only one language of all that he has overviewed in his typological study has masculine as the marked gender). Pragmatics does the rest of the work: the value denoting either gender by implicature becomes prone to a masculine interpretation, because if the speaker aimed at the female presupposition, (s)he would have used the marked form. The male interpretation of the masculine gender is thus rather a derived implicature for a value which is otherwise unspecified for gender.

In this way, grammar manages to express all the three meanings: male, female and unspecified/mixed by using only two values: masculine (i.e. unspecified) and feminine. Considering the abundant presence of gender in grammar (in each nominal expression, on all attributive, appositive and 
predicative elements involving adjectival items be they adjectives proper or participles), this tiny gain results in an enormous overall 'saving' on the side of both processing and memory.

The question emerges why in almost all gender languages of the world it is the male presupposition that is derived from the default value by implicature. The direct reason is most probably that masculine gender is more frequent (my corpus research on Serbo-Croatian shows that the number of feminine nouns is somewhat larger than that of masculine nouns, but the number of masculine nouns occurring per 1000 words of corpus is significantly higher than the number of feminine nouns). It is more economical to have the more frequent value realized in an unmarked way, as the overall gain in economy is then higher. And the fact that the masculine nouns are generally more frequent than feminine in one language after another probably reflects the dominant cultural status of men.

The other aspect of economy in the domain of gender relates to the trade-off between memory and the productive generation characteristic in general of the relation between lexicon and grammar. Lexicon is, roughly speaking, a storage of idiosyncratic sound-meaning pairs, which grammar combines to derive compositional complex expressions (complex expressions whose meaning is a function of the meanings of their parts and the structure in which the parts are fitted). When two concepts are related, such that one can be expressed in terms of the other plus some additional material, there are two options:

1. that both meanings receive independent phonological realizations and are independently stored in the lexicon (e.g. krava : bik 'cow : bull'), or

2. that one of them is stored in the lexicon, and the other is derived by grammar and some additional material (e.g. magarac : magaric-a 'donkey : she-donkey').

Option 1 is more economical when both these words are highly frequent, so it is 'cheaper' to have them both ready in our memory than to have to derive one of them each time it is needed. The other option is more economical when at least one of the words fails to reach the frequency necessary for lexicalization. In such cases, it will be the more frequent one among them that is memorized, and the less frequent one that is productively derived from it. The number of words frequent enough to be independently lexicalized in spite of the possibility of being derived 
is small: dozens of thousands times smaller than the number of the ones whose frequency leaves them to be derived.

If it happens that certain derivable concepts, due to social and cultural changes, gain higher frequency, they may end up memorized (e.g. that the complex structure of magaric-a 'donkey-Fem' be collapsed and the word thus be memorized as a whole, with an idiosyncratic meaning, fully dissociated from magarac 'donkey'). Yet it is an important aspect of the economy of language that each meaning that can be derived from a more frequently occurring meaning which has an own lexical item should also be linguistically realized by an expression derived from that item unless its frequency grants it idiosyncratic memorization.

This holds of gender pairs as well. The reason why krava and bik 'cow, bull', svinja and vepar 'pig, boar', kučka and pas 'female, male dog' have idiosyncratic lexemes and magaric-a and magarac 'donkey', zeč-ica and zec 'rabbit', sokol-ica and soko 'hawk' are derivationally related lies in the high frequency that the former have had for a very long period in human history, unlike the latter. And we should not be surprised if we start hearing about krav-ac 'cow-Masc', or pas-ica 'dog-Fem' now that the frequency does not entirely support idiosyncrasy any more.

In a vast majority of cases, the masculine term is memorized, and the feminine is derived (probably for the reason that masculine is the default value of the formal feature of gender, as discussed above). In those cases, the former is either without any suffix (zec : zeč-ica), or sometimes has a masculine suffix to which a feminine suffix gets added (ov-an : ov$c a$ 'sheep'). There are, however, also cases where the feminine term is memorized, and the masculine term is derived, as in lis-ac : lis-ica 'fox', gus-an : gus-ka 'goose'. The memorized member of the pair can be attested by overarching interpretation tests:

Svi zečevi vole repu. ( $\Rightarrow$ females too)

'All rabbits like turnip'

Sve zečice vole repu ( $\neq>$ males too)

'All she-rabbits like turnip'

Svi lisci vole repu. ( $\neq>$ females too)

'All he-foxes like turnip'

Sve lisice vole repu $(\Rightarrow$ males too)

'All she-foxes like turnip' 
Svi bikovi vole repu ( $\neq>$ females too)

'All bulls like turnip'

Sve krave vole repu ( $\neq>$ males too)

'All cows like turnip'

On the one hand, these examples show that the masculine gender is not the absolute default at this level of economy (unlike among the values of the formal feature of gender), as there are cases where the feminine form covers both genders and the masculine denotes only males. But on the other, it confirms, or conforms, the default status of the masculine in the sense that feminine can derive from the masculine (zec>zečica), but masculine is never derived from feminine - at best both masculine and feminine are derived from a common base (lis-ac, lis-ica). This turns out to be a general restriction, as most of the animal terms with a feminine default do not even derive a masculine term (žirafa> ??žiraf-ac/??žiraf-an, riba> *ribac).

Let me sum up: it is significantly more economical to have one unspecified formal value of gender, relating by implicature also to the more frequent biological gender, and one marked formal value restricted to the less frequent biological gender, than to have two marked values and an unspecified one; and it is significantly more economical to have female and male terms for the same insufficiently frequent notion derived from one another, or derived both from the same stem, than to have them idiosyncratically memorized.

\section{Gender-sensitive language, and gender-sensitive Serbo-Croatian}

The battle for a gender-sensitive Serbo-Croatian has mostly been fought with two goals. One is based on the view that language shapes our world views - and that hence the difference in the marking of men and women, or males and females, results in an asymmetric culture, in which men and women are not equal. Consequently, balancing the marking of the two genders in language may create a better society in which men and women will be close to equal. The other goal is based on the fact that masculine terms for humans are significantly more frequent in language, and on the view that the resulting lower visibility of women in language is the cause of a range of stereotypes about their lower participation in society - especially 
when it comes to prestigious social roles, which is further interpreted as a consequence of their lower abilities in the respective areas. Hence, negative stereotypes about women can be weakened by increasing the visibility of women in the society, which in turn can be achieved by increasing their visibility in language.

Needless to say: these two goals are in mutual opposition. The ideal outcome of the former would be an equal status of the feminine gender compared to the masculine - in terms of markedness, as well as in terms of quantitative representation in language use. The ideal outcome of the latter includes a higher degree of markedness and a denser presence of the feminine terms compared to the masculine counterparts in the language.

As for this latter goal - to increase the marking of women (with prestigious titles, positions, professions) in language, it clearly favors the strategy involving the prefix žena- 'woman' to suffixal derivation, for its higher markedness: the prefix explicitly introduces the concept of a woman, it is stressed and forms a semi-composed noun, thus preserving a higher degree of independence and crucially: visibility. Its flaw is that visibility and markedness do not necessarily correspond to a better status. Quite the other way around: in a culture in which the man is dominant and has a more positive image than the woman - increasing the visibility of the woman may additionally stress this asymmetry.

The other goal, aiming for linguistic symmetry, relies on the hypothesis that language shapes our minds and our culture, which is highly controversial. Ever since Sapir and Whorf, it has figured prominently in linguistics, yet every attempt to test it has eventually been proven inconclusive (see for instance Li and Gleitman 2002 for one such episode). If there is a worse destiny for a hypothesis than being proven false - it is failing to generate valid tests.

But one can set a more modest goal than removing asymmetry from language, and go for shallower layers of language than the economy of its asymmetric organization. It is easy to see how the fact that for instance most of the profession terms that only have a feminative are professions of low prestige (dadilja 'nanny', kafe-kuvarica 'coffee-maker', kurva 'prostitute'), while those without traditionally used feminatives are rather balanced between prestigious and non-prestigious vocations (inženjer 'engineer', vođa 'leader', ubica 'killer') may trigger generalizations and associations which are not favorable for women.

Feminists interpret this situation as a direct consequence of gender inequality: there are stereotypical social roles connected with men and with 
women. The solution is seen in the introduction of feminine counterparts for every masculine term denoting a profession title or other social role, especially for those with positive connotations. However, while the interpretation above is correct, it recognizes only one out of two important factors. The other factor is grammar: its constraints and its economy. Due to the fact that masculine gender is realized though pragmatic implicature, as the interpretation of the disjunctive formal gender (masculine_or feminine - see section 3), feminatives are universally derived from default/ masculine forms. They are therefore not only universally more cognitively expensive, but they also universally involve one additional morphological operation, which comes with its own grammatical constraints. Derivational morphology is generally relatively idiosyncratic in terms of which suffixes can combine with which bases (which is one of the defining properties of morphological derivation, distinguishing it from inflection), and it is for this reason generally full of gaps - items which in principle could be derived, but in reality, due to the selective behavior of affixes and the properties of the respective bases, do not actually exist. Therefore, also in the field of feminatives - there is a large number of those which in principle should exist, but actually cannot be derived, or when derived - give the effect of degraded grammaticality.

In other words, there are a number of expected feminatives whose derivation is blocked by certain morphological or phonological principles. Such is the case with the forms ?'borkinja 'she-fighter', ?'vodkinja 'sheleader', ?'lovkinja 'she-hunter', ??prevodilica 'she-translator'which all violate certain grammatical constraints. ${ }^{2}$

This means that the fact that there are fewer feminatives for prestigious social roles than for the negatively connoted ones is a consequence of two

2 It was pointed out to me that prevodilica is not the proper way to derive a feminative for the translator, and that prevoditeljka is not degraded at all. I agree with this observation, but part of the feminist struggle regarding Serbo-Croatian is exactly in promoting alternative feminatives, hence psihološkinja is favored over the less marked psihologica 'she-psychologist' etc. I quote an illustrative comment by a woman I found on a social network: ,jer stvarno, ja već gubim nadu da će ikada svanuti dan kada ću ja moći visoko uzdignute glave da kažem da sam po zanimanju PREVODILICA, a da moj sagovornik ne otrči bezglavo u toalet zbog iznenadnog naleta dijareje ili me ne isprska sadržajem svoje usne šupljine u nekontrolisanom napadu smeha... stvarno, umreću isfrustrirana" ['because really, I'm already losing hope that the day will ever come when I'll be able to proudly say that I'm a she-translator [i.e. prevodilica] by profession, without the hearer running to the toilet for a sudden attack of diarrhea or spraying me with the contents of his mouth in an uncontrolled attack of laughter... really, I'll die frustrated']. 
main factors. One is the unequal status of genders, which has prompted the derivation of a higher number of feminatives of the latter type. The other is the combination of a higher grammatical complexity of feminatives with the partial productivity of strategies of morphological derivation. Without the latter component, all the relevant terms would have a derivable feminative, effectively eliminating any asymmetry.

The response from the feminist side is that grammar is irrelevant, since once these terms are introduced and used for a while, they cease to sound degraded and become fully acceptable. And it is correct. So if we really care for equality, we can simply keep on using these words even if we feel them grammatically degraded, until they start sounding neutral.

The problem here is that the degradation is erased by what linguistics refers to as lexicalization - a process whereby the internal structure of a complex word is collapsed and the meaning of the word is memorized as idiosyncratic rather than compositionally derived. Exactly the process that has been described in section 3 as licensed by the sufficiently high frequency of the respective lexical item. Thus indeed, if we keep repeating the respective words often enough, they will join our lexicon as regular nouns. But only on the condition that we use them frequently enough.

This is why borkinja 'she-fighter', which is a term used for an activist, and hence very frequent in feminist discourse, feels, within this discourse, highly normalized. As opposed to the noun lovkinja 'she-hunter', which, due to its low frequency in more or less any present day discourse, sounds quite unnatural even though it is listed in the reference dictionaries. Frequent words prone to lexicalization like borkinja will indeed relatively soon stop sounding degraded even to the conservative ear. For this reason, the real target of discussion are nouns like ??strelkinja/\#strelica ${ }^{3}$ ?'streliteljka 'shearcher, markswoman' or ?"pošiljalica/?pošiljalkinja/ ?"pošiljateljka 'shesender', which are not highly frequent, and which do sound degraded on purely grammatical grounds. Here the feminist activists are quite unified in considering the use also of the infrequent feminatives a necessary part of a gender sensitive language, and the conservative side suggests that terms like žena-strelac 'woman-archer, woman-marksperson' and ženapošiljalac 'woman-sender' be used instead. Feminists, in turn, judge such terms cumbersome, and suggest that we simply use the derived feminatives until they begin to sound normal. However, this is based on an incorrect premise: (most of) these nouns are insufficiently frequent, and since the

3 The word strelica exists, but only as the diminutive of the noun strela 'arrow'. 
amount of derivable nouns that are idiosyncratically memorized is limited by economy, they are not likely ever to be lexicalized. As that means that they can only keep being productively morphologically derived, and in productive morphological derivation grammatical constraints play a crucial role - it is also highly unlikely that they will ever start sounding normal.

In other words, there is no good will strong enough that can force our brain to memorize thousands of derived lexical items - be they derived as grammatical or ungrammatical. The pressure not only of economy, but also of the limitations of our memory, is simply too strong to tolerate this kind of a shift in language.

But at the same time, note also that the limitations on the derivational productivity of feminatives holds equally for all the relevant notions - both the positively and the negatively connoted ones. The percentage of grammatically degraded feminatives among positively and negatively connoted notions is stable - consider these very negative terms without a derivable feminative: dripac 'punk', but *dripka/*dripica/*dripkinja (intended: 'she-punk'), ubica 'murderer', but *ubička/*ubičkinja/*ubilica (int: 'she-murderer); skot 'brute', but "skotka/"skotkinja/*skotica; seronja 'asshole', but "seronjka/"seronjkinja/"seronjica; bilmez 'gowk', but *bilmezka/*bilmezkinja/"bilmezica (int. 'she-gowk'). ${ }^{4}$

Morphological limitations in themselves do not contribute to the asymmetric distribution of feminatives across the prestigious and stigmatized social roles - they equally affect both these semantic fields. The uneven distribution is entirely determined by cultural models and views: among the grammatically possible derived forms, there is a higher number of actually derived feminatives with a negative, than with a positive connotation because that reflects the stereotypes and perhaps to some extent the reality in the respective society (there are more women carrying non-prestigious than prestigious social roles, and the other way around for men). The only way to really change this situation is not to have a fully productive derivational system (which is a contradictio in adjecto, since derivation is by definition idiosyncratic), but to have a culture characterized by gender equality. Such a reality would relatively

$4 \quad$ I received comments that $u b i c a$ and seronja are already feminine as they end in - $a$, but this is plainly false: these nouns, just like the nouns deda 'gradfather', teča 'uncle' are masculine even though they end in $-a$, as evidenced by the agreement they trigger: surovi/"surova ubica 'cruel.Masc/Fem murderer', ovaj/*ova seronja 'this.Masc/Fem asshole'. 
quickly get its reflex in language. Language reacts to frequency, and it does not react to artificial interventions and campaigns. Hence the entire idea of reshaping the culture by means of a controlled change of language is a misconception.

Crucially, every asymmetry that grammar shows is neutral when it comes to the system of values, except indirectly: it will often reflect an asymmetry in the frequency of occurrence, and this asymmetry may reflect an uneven status of the corresponding concepts, in particular of the woman and the man. Even then - language only reflects the frequency, it does not determine it. It is perfectly possible that a grammar be organized in the inverse way: that there is a masculine_or_feminine form which is also used for feminines, together with a marked masculine - and that the status of the man and the women in the society still favors men in the same degree and manner as it does in Serbian society. Any grammatical asymmetry is able to encode, i.e. reflect any cultural asymmetry. The grammatical asymmetry is arbitrary with respect to the asymmetry concerning the system of values.

\section{Can there be a gender-equal language?}

In the preceding sections, I have argued that:

1. Asymmetric organization of grammar (including the gendersystem) is more economical, and language undergoes strong pressure for economy - which makes it unlikely that a symmetric structure can be imposed on the gender system of Serbo-Croatian.

2. There are grammatical obstacles to a fully productive system of derivation of feminatives, and only a very limited number of feminatives can be lexicalized - hence there can never be a (Serbo-Croatian) language with both a feminine and a masculine form for each relevant notion.

3. Neither of these asymmetries in and of itself carries or imposes an asymmetrical status of genders in the culture - the latter asymmetry can be projected on any asymmetric linguistic structure, and it would exist to an equal extent without a linguistic carrier too. 
4. Consequently, language cannot be instrumental in reshaping the culture - but it will always react, even if relatively slowly, to cultural changes and equally efficiently reflect any system of values that the culture reads into it.

Still, one may argue that the fact that genders are organized in an asymmetric relation in grammar supports their asymmetric status in cognition and culture, and that a symmetric one would make it easier to achieve a higher degree of equality in the society. This poses the question: Can language achieve full gender-equality?

The answer depends on the interpretation of the question. One interpretation targets grammar. And here the answer is very easy: yes, grammar can be gender-neutral, and hence also gender-equal. Corbett (1991) reports that about a half of the world's languages involve a grammatically significant classification of nouns based on sex. This shows how prominent classification based on biological gender is, but also that about one half of grammars in the world are gender-neutral.

If the question also refers to individual lexical items and their gender semantics, then there are probably no languages in the world without any words reserved for women as bearers of social roles. In this interpretation, a gender-equal language would need to have approximately the same number of words reserved for women and for men, and no gender should be derived from the default gender semantics. In principle, there is nothing against the existence of such languages either - but their existence is conditioned by the existence of a gender-equal culture in which they are spoken and a sufficiently long period of time for the language to accommodate to such a culture.

Paradoxically, the feminist action is not bringing Serbo-Croatian closer to a gender-neutral language. A precondition for the emergence of such a language is that the classification of nouns based on gender semantics reaches such a high level of grammaticalization that it gets completely disjoint from the gender component. Giving gender a prominent place in the debate around gender equality secures it a prominent status, and its realization in the domain of language (e.g. the derivation of feminatives) hinders or even reverts the process of grammaticalization in neutralizing gender semantics. 


\title{
References
}

Arsenijević, B. (2017). Gender, like classifiers, specifies the type of partition: evidence from Serbo-Croatian. Chicago Linguistic Society 52, 21-23.

Corbett, G. (1991). Gender. Cambridge: Cambridge University Press.

Li, P. and L. Gleitman (2002). Turning the tables: Language and spatial reasoning. Cognition, 83(3), 265-294.

Received: 14 November 2017

Accepted for publication: 31 January 2018

Бобан Арсенијевић

\author{
ЈЕЗИК ДОРИЈАНА ГРЕЈА: ЗАШТО СОЦИЈАЛНИ И КУЛТУРНИ СТАТУС \\ РОДОВА НЕ МОЖЕ БИТИ УНАПРЕЪЕН ДЕЛОВАҢЕМ НА ЮИХОВ ОДРАЗ \\ У ЈЕЗИКУ
}

\section{Сажетак}

Рад разматра интеракцију феминистичке идеологије и акције на једној и дубље граматичке структуре и лексикона на другој страни. Тврди се да лингвистичка интервенција пропагирана као начин за постизање родне једнакости нити може да буде успешна нити теоријски пројектује језик који карактеришу жељене особине. Понуђени су аргументи против става да језик обликује стварност, а у корист обрнуте ситуације, где језик одражава већ установљену слику света и у најбољем (или најгорем) случају помаже да се она очува. Закључак коме рад води је да је у друштву у коме језик није оса дискриминације - сваки лингвистички статус граматичког рода једнако добар, али да би такво друштво вероватно на крају развило језик у коме род нема никакву граматикализовану улогу.

Кључне речи: граматички род, родна једнакост, родно осетљив језик, српскохрватски, језичка економија 